\title{
Defatted coagulant seeds of Moringa oleifera and Moringa peregrena mediate alleviation of cadmium toxicity in wheat (Triticum aestivum L.) plant
}

\author{
Raifa A. Hassanein ${ }^{2}$, Amal F. Abdelkader ${ }^{1,2} *$, Heba M. Faramawy ${ }^{2}$ \\ ${ }^{1}$ Department of Biological Sciences, College of Science, King Faisal University, P.O.380, El-Ahassa \\ 31982, Saudi Arabia \\ ${ }^{2}$ Department of Botany, Faculty of Science, Ain Shams University, 11355, Cairo, Egypt
}

*Corresponding author: aabdelkader@kfu.edu.sa; amal.abdelkader@yahoo.com

\begin{abstract}
Contaminated soil with toxic heavy metals, particularly cadmium, is an environmental originated challenge from various industrial activities such as effluents and mining and affecting crop growth. Cadmium removal from the soil is a problem, therefore we introduced our approach for reinforcing cadmium tolerance in wheat plant by applying powder ( $1 \mathrm{~g} / \mathrm{kg}$ soil) of fat-free seeds 'defatted seed or seed-cake' from Moringa oleifera and Moringa peregrena trees before wheat exposure to three levels of soil contamination with cadmium in soil solution $(0.5,1.0$ and $1.5 \mathrm{mM})$ for 35 days. Our data showed that accumulation of $\mathrm{Cd}$ in wheat was concentration-dependent and was 4-folds higher in roots than in the shoots. In shoots and roots, cadmium accumulation was 3- and 2folds higher at $1.5 \mathrm{mM} \mathrm{Cd}$, respectively. Shoot length and dry mass have reduced by 30 and $58 \%$, respectively. In addition, the photosynthetic pigments have decreased by $50 \%$ and the protein profile was altered in leaf. Moringa defatted seeds powder had conferred protection against cadmium toxicity in wheat. Upon defatted seeds pre-treatments, Cd accumulation has diminished by 3 and 2-folds in shoots and roots, respectively and wheat growth and physiological parameters have improved spectacularly. Protein polymorphism and SDS-gel electrophoresis confirmed the appearance of eight newly expressed protein bands in response to Moringa pre-treatments in absence of $\mathrm{Cd}$. Eleven new bands were also expressed under the combined effect of cadmium and Moringa together in wheat leaf and weighed: $261.38,217.77,177.38,135.4,114.0,97.0,74.14,51.6,38.2,24.0$ and $13.5 \mathrm{KDa}$. We believed that the new bands have participated with wheat tolerance. In conclusion, we suggested two strategies: first, Moringa seeds have coagulated cadmium in the soil preventing its absorption and accumulation in wheat plants. Second, wheat newly expressed protein has assisted cadmium detoxification via binding to some peptides, and/or through sequestrating cadmium in the vacuole as metallothioneins and/or polychelatins.
\end{abstract}

Keywords: Cadmium, Moringa sp, SDS-PAGE, seed cake.

\section{Introduction}

Released and deposited wastes which produced from various activities particularly those emerged from the industrial effluent and mining are crucial environmental pollutants causing deleterious impacts on the ecosystem (Lenardao et al., 2003). Cadmium is considered as the most poisonous heavy metal even at low concentrations (Yurtsever and Sengil, 2009). Alternatively, excessive amount of cadmium in the soil causes toxic symptoms to plants such as chlorosis, growth inhibition, browning of root tips and finally death (Guo et al., 2008). Recently, these toxic heavy metals in the soil became a threat for human health due to their incorporation into the food chain (Bazrafshan et al., 2013). There are number of synthetic polymers were especially made for the removal of heavy metals such as carbon polymers, which has so far participated with effluents treatments (Wan Ngah and Hanafiah, 2008). In addition, aluminium sulphate, poly-aluminium silico sulphate, ferric acids, and soda ash were chemical candidates employed for metal detoxification (Bazrafshan et al., 2013). Nonetheless, using these materials excessively and on large scale found to become costly and detrimental to environment (Ahluwalia and Goyal, 2007). Thus, fetching alternative, cost low, highly efficient adsorbents attracted concerns with the raised global demand (Choong et al., 2007). Since all natural by-product are usually safe, stakeholders tended to exploit alternative organic materials like agricultural wastes and agro-industrial characterized for being largely producible and relatively inexpensive with their capability as bio sorbents of metal ions (Santos et al., 2011). They also have advantages as being biodegradable, non-risky in their impacts on health and environment (Mahdavi et al., 2012).

From the literature, Moringa was the tree of choice, it often acted as bio-remediator for housing seeds with potential environmental effects (Iqbal and Bhanger, 2006; Juliana et al., 2009; Sarwatt et al., 2002). In this study, we investigated the role of two Moringa species on cadmium detoxification in wheat culture. The first species: Moringa oleifera characterized by grown-seeds in brown pods, each pod contains 10-50 seeds (Vlahof et al. 2002). When seeds become dry, they rounded in shape or got triangular, surrounded with wooden shell and attached with three delicate wings (Qaiser, 1973). Seeds were used for many purposes; as food, in medicine, and in water purification (Coppin et al., 2013; Ndabigengeser and Narasiah, 1998). Extracted seeds contained $33-41 \%$ oil and possessed powerful antioxidant property (Sengupta and Gupta, 1970). 
The residue originated from oil extraction (seed-cake) was used as fodder and biofertilizers (Meneghel et al., 2013; Santana et al., 2010). However, the active components accumulated in seed were usually soluble proteins and peptides of low molecular weights (Gassenschmidt et al., 1995; Ndabigengesere et al., 1995). Among these components, the purified MO2.1 peptide possessed flocculent activity on glass powder suspension, and on bacteria and clay particles (Gassenschmidt et al., 1995; Suarez et al., 2003). The seed by-product enclosed all active components together usually have cumulative effect and used for discarding pollutants from aqueous solutions, clarified, adsorbed particles, and resulted in turbidity decrease by 51 to $61 \%$ (Himesh et al., 2007; Okuda et al., 2001).

The second species: Moringa peregrena Forssk, is one of the most economically important plant in Egypt (Abd Elwahab et al., 2004). Many parts of this tree like leaves and pods possessed nutritional value for human and livestock. It also contained compounds as vitamin A, B and C, minerals and calcium. Leaves were good source of protein, and the extracted oil been used in folk medicine as lubricants (Alkahtani and Abu Arab, 1993) and in cosmetics due to its non-sticking and odourless character (Nautiyal and Venkataramen, 1998). Little is known about the role of Moringa peregrena as pollutants coagulant. However, its efficiency as bio-remediator was suggested due to its richness in vitamins, minerals and proteins.

The present study was conducted to examine the possible pre-treatment effect of defatted Moringa oleifera seeds on detoxification of cadmium in wheat plants. The coagulant role of Moringa peregrena defatted seeds was also investigated in parallel and for the first time in this research study.

\section{Results}

\section{Cadmium effect on wheat growth and physiological parameters}

In absence of Moringa seed-cakes, the overall results showed intensive cadmium accumulation in shoot and root of cultured-wheat with cadmium. However, the accumulation level was concentration-dependent and the increase was particularly significant in roots than in aerial parts (Fig 1). For example, when $\mathrm{Cd}$ concentration had increased in the soil solution from $0.5 \mathrm{mM}$ to $1.5 \mathrm{mM}, \mathrm{Cd}$ accumulation was increased by 3 - and 2-folds in shoot and root, respectively. The data also revealed significant decrease in wheat shoot length with the increasing cadmium concentration (Fig 2A, Supplementary Fig 1). The shoot length has decreased by $30 \%$ when $1.5 \mathrm{mM}$ of cadmium was applied to the soil as compared to cadmium-free culture. Similarly, the reduction of other growth parameters in exposed wheat to $\mathrm{Cd}$ during growing without seed-cakes was $58.3 \%$ and $40 \%$ of shoot fresh and dry weights, respectively. Root fresh and dry weights have reduced to half and to one third, respectively. In addition, the relative water content has decreased by $50 \%$ (Figs 2D-F).

Photosynthetic pigments were affected with the increased cadmium concentration in the soil solution. The decrease in chl $a$ reached 1.6 and 2.5-folds, while the decrease in chl $b$ and the carotenoids was 1.4- to 2.1-folds and 1.0- to 1.7folds, respectively at 0.5 and $1.5 \mathrm{mM}$ cadmium concentrations (Figure 3).
OS and PS enhanced wheat growth and maintained pigments under Cd toxicity

At $1.5 \mathrm{mM} \mathrm{Cd,} \mathrm{Moringa} \mathrm{oleifera} \mathrm{(OS)} \mathrm{seed-cake} \mathrm{pre-}$ treatment decreased $\mathrm{Cd}$ by 3 -folds in the shoot and by 2-folds in the root. The same was observed with Moringa peregrena (PS) pre-treatment, as Cd was decreased by 3- and 1.6-folds in the shoot and the root, respectively (Fig 1). Applications of OS and PS had induced up regulations in shoot lengths above the control (Supplementary Figs 2,3). The best recovery was particularly detected in OS. However, applications of OS and PS had caused $86.5 \%$ and $26.8 \%$ increase of shoot fresh and dry weights, respectively (Fig $2 \mathrm{~B}$ and 2C). Regarding pigment recovery from cadmium stress, the role of OS was much more important compared to PS (Fig 3, supplementary Figs. 1, 2 \& 3).

\section{OS and PS altered protein profile in grown wheat with $C d$ toxic effect}

Protein banding pattern of leaf from wheat plants grown under normal water irrigation conditions revealed 15 bandexpressions: $182.24,105.6,100.6,89.0,63.41,58.5,55.0$, 47.8, 42.2, 36.0, 32.78, 27.1, 25.0, 21.43, and 15.87 KDa. The control band (182.24 KDa) has never expressed again in grown wheat under the treatments. Cadmium effect at 0.5 or $1.5 \mathrm{mM}$ was similar in inducing the expression of total five protein bands: $217.77,135.4,51.6,45.0$, and $38.2 \mathrm{KDa}$. In addition, the two bands, 261.38 and $170.92 \mathrm{KDa}$ were detected at only $0.5 \mathrm{mM}$, and the three bands weighed 114.0 , 97.0 and $71.14 \mathrm{KDa}$ have appeared in wheat leaf upon the exposure to $1.5 \mathrm{mM}$ cadmium. Generally, the polymorphism was $43.7 \%$ and $47 \%$ for 0.5 and $1.5 \mathrm{mM}$ cadmium, respectively (Fig 4, Table 1 ).

Applications of defatted seeds powder of OS and PS in the growing wheat have induced the expression of total sum of eight new bands. Among which, four protein bands were shared between the two species: 225.85, 190.31, 116.0, and $68.3 \mathrm{KDa}$. However, the $29 \mathrm{KDA}$ band was expressed by OS seeds whereas the two bands at 145.1 and 14.2 KDa were PS expressed-protein bands. The polymorphism for OS and PS was $43.1 \%$ and $41 \%$., respectively.

The combined effect of cadmium and Moringa seeds had resulted in the appearance of eleven new bands in wheat leaf: 261.38, 217.77, 177.38, 135.4, 114.0, 97.0, 74.14, 51.6, 38.2, 24.0 and 13.5 KDa. The heaviest band of $261.38 \mathrm{KDa}$ was not expressed in OS+0.5 mM Cd. In addition, the bands: 24 and $13.5 \mathrm{KDa}$ were expressed by solely OS. The highest polymorphism was $63.1 \%$ and was shown under OS+0.5 mM Cd treatment. In contrast, the polymorphism of $47.3 \%$ was shown in PS+0.5 mM Cd. The polymorphism was $50 \%$ when $1.5 \mathrm{mM} \mathrm{Cd}$ was combined to either OS or PS (Table 1).

\section{Discussion}

In the present study, the by-product, seed cake was produced following oil extraction, drying and grinding seeds of Moringa oleifera (OS) and Moringa peregrena (PS). In the previous studies, six protein bands from Moringa seeds were detected and their coagulant ability in binding heavy metals and forming complexes was described (Bazrafshan et al., 2013). Globulin, albumin, prolamins, and glutelin were purified as Moringa coagulant proteins (Derbyshire and Wright, 1976; Baptista et al., 2017). Application of OS and PS either without stress or in combination to cadmium in soil had disclosed their important role in coagulating cadmium ions resulting in less cadmium accumulation in wheat shoot 
Table 1. Polymorphism and monomorphism of leaf soluble protein of pretreated wheat (Tricticum aestivum) with Moringa seeds and cadmium. Control wheat $\left(\mathrm{H}_{2} \mathrm{O}\right)$, contaminated wheat with cadmium $(0.5$ and $1.5 \mathrm{mM})$, pretreatment with defatted M.oleifera powder (OS) or M.peregrena seeds powder (PS). Combined effect of both cadmium and Moringa seeds powder: (OS, Cd 0.5, $1.5 \mathrm{mM})$ and (PS, Cd 0.5, $1.5 \mathrm{mM})$.

\begin{tabular}{|c|c|c|c|c|c|c|c|c|c|}
\hline $\begin{array}{l}\text { Protein bands } \\
\text { M wt } \\
\text { KDa }\end{array}$ & $\mathrm{H}_{2} \mathrm{O}$ & $\begin{array}{c}\mathrm{Cd} \\
0.5 \mathrm{mM}\end{array}$ & $\begin{array}{c}\mathrm{Cd} \\
1.5 \mathrm{mM}\end{array}$ & OS & PS & $\begin{array}{c}\text { OS } \\
(\mathrm{Cd} 0.5 \mathrm{mM})\end{array}$ & $\begin{array}{c}\text { PS } \\
(\mathrm{Cd} 0.5 \mathrm{mM})\end{array}$ & $\begin{array}{c}\mathrm{OS} \\
(\mathrm{Cd} \mathrm{1.5} \\
\mathrm{mM})\end{array}$ & $\begin{array}{c}\text { PS } \\
(\mathrm{Cd} 1.5 \mathrm{mM})\end{array}$ \\
\hline Total no. & 15 & 16 & 17 & 16 & 17 & 19 & 19 & 14 & 18 \\
\hline No. of monomorphic bands & - & 9 & 9 & 9 & 10 & 7 & 10 & 7 & 9 \\
\hline No. of polymorphic bands & - & 7 & 8 & 7 & 7 & 12 & 9 & 7 & 9 \\
\hline$\%$ polymorphism & - & $43.7 \%$ & $47 \%$ & $43.7 \%$ & $41.1 \%$ & $63.1 \%$ & $47.3 \%$ & $50 \%$ & $50 \%$ \\
\hline
\end{tabular}

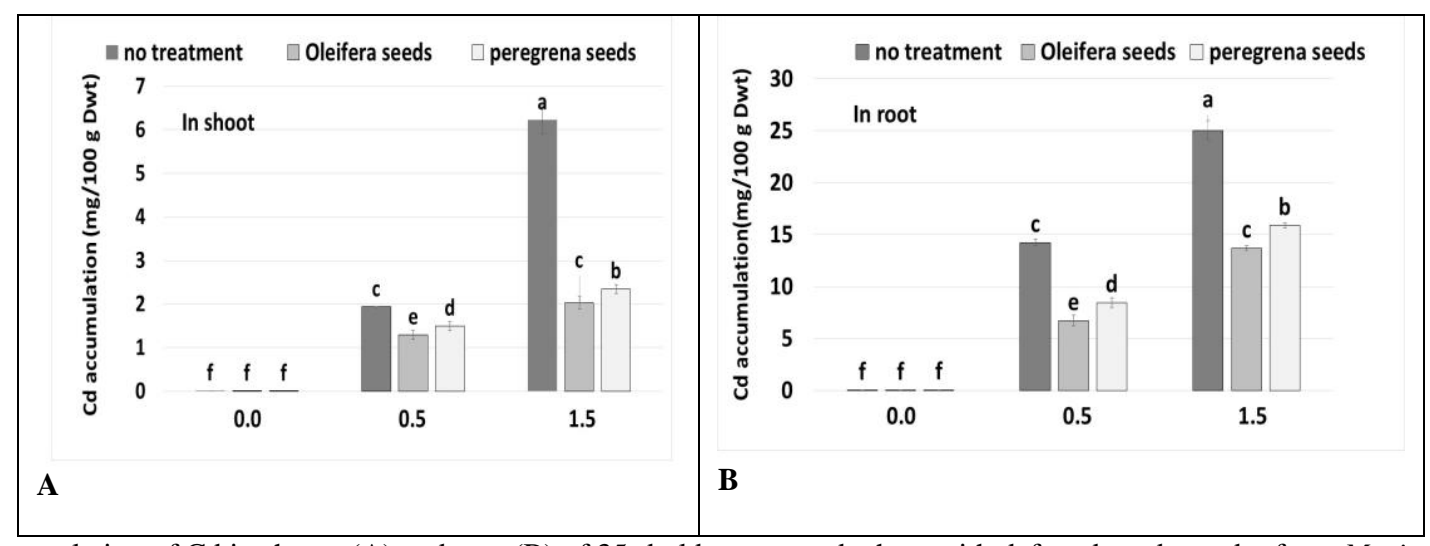

Fig 1. Accumulation of Cd in shoots (A) and root (B) of 35-d old pre-treated wheat with defatted seed powder from Moringa oleifera and Moringa peregrena before grown without $(0.0) \mathrm{Cd}$ or with $\mathrm{Cd}: 0.5$ and $1.5 \mathrm{mM}$. Bars associated with different letters are significantly different (one-way Anova, LSD test, $p \leqslant 0.05$ ).

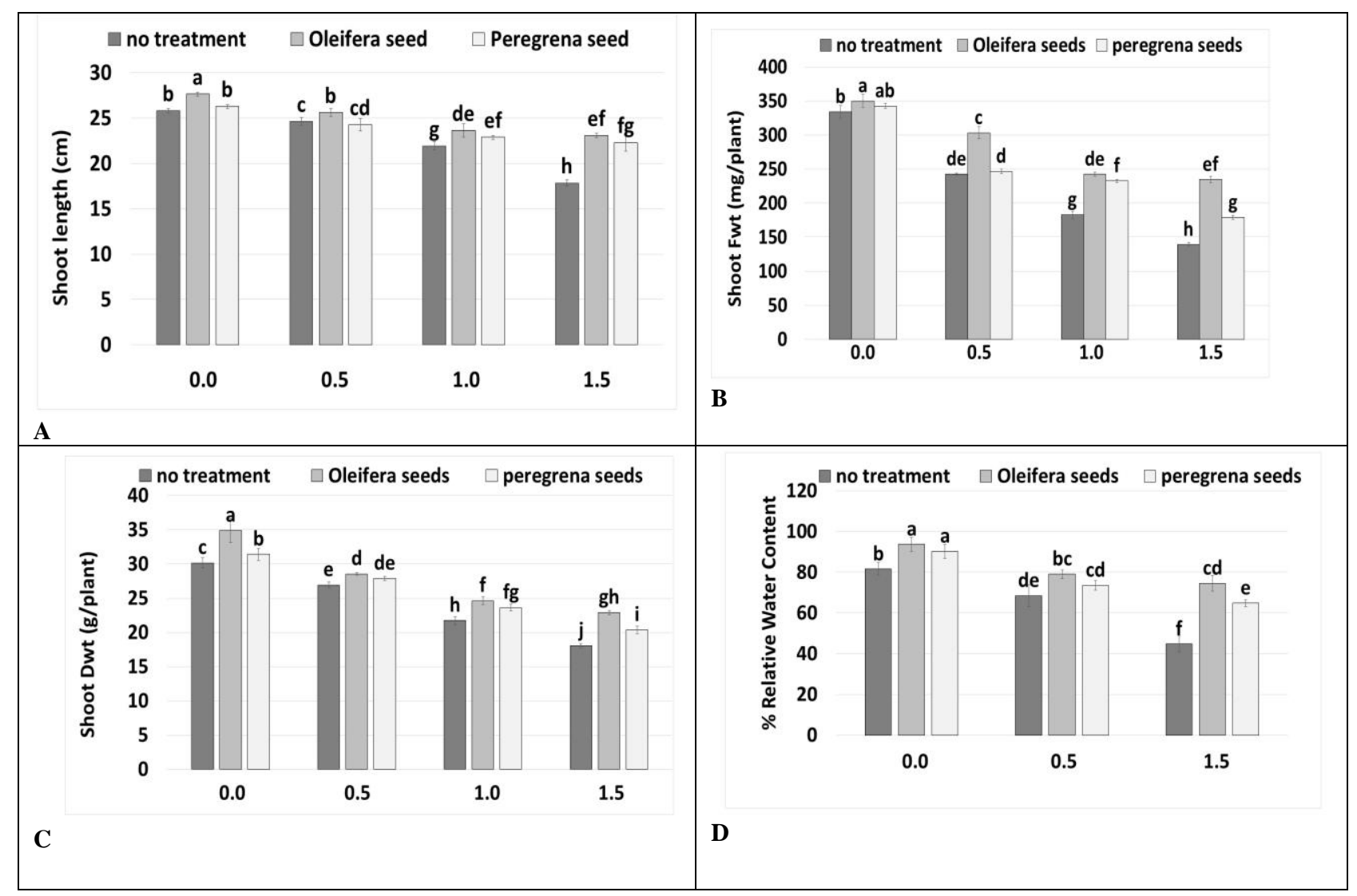




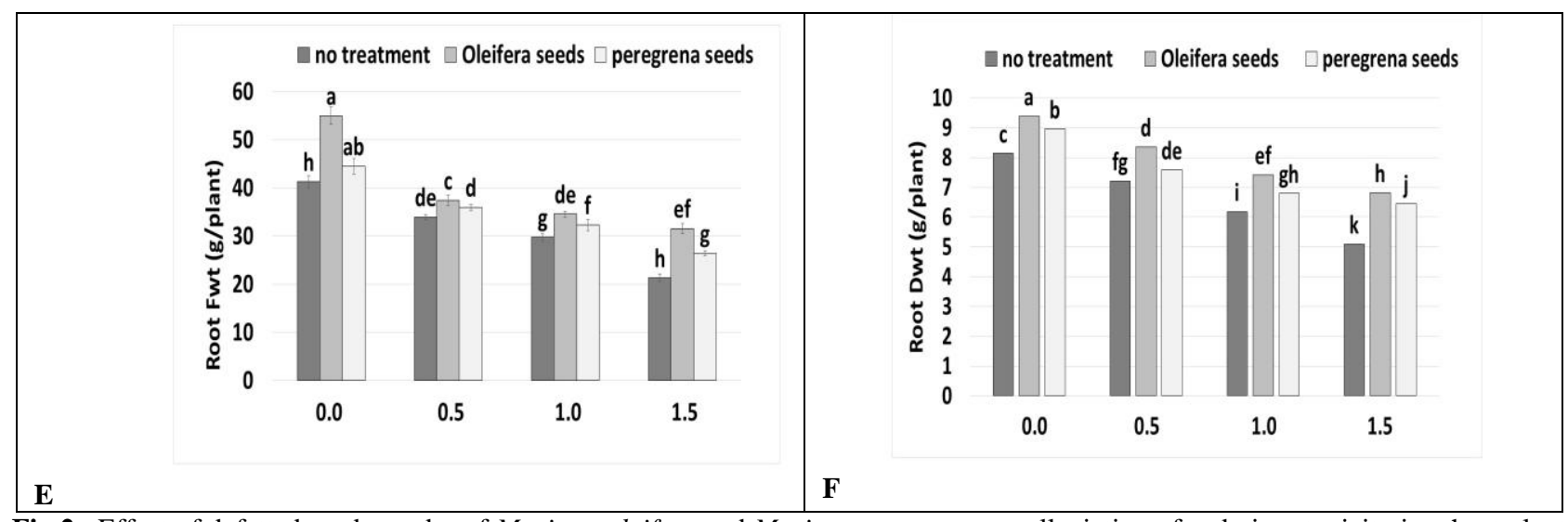

Fig 2. Effect of defatted seed powder of Moringa oleifera and Moringa peregrena on alleviation of cadmium toxicity in wheat plant grown without cadmium or with $0.5,1,1.5 \mathrm{mM}$ cadmium acetate as indicated in the morphological parameters. shoot length; A, shoot fresh weight; B, shoot dry weight; $\mathrm{C}$, root fresh weight; $\mathrm{E}$, root dry weight; $\mathrm{F}$ and the relative water content; D. Bars associated with different letters are significantly different (one-way Anova, LSD test, $p \leqslant 0.05$ ).

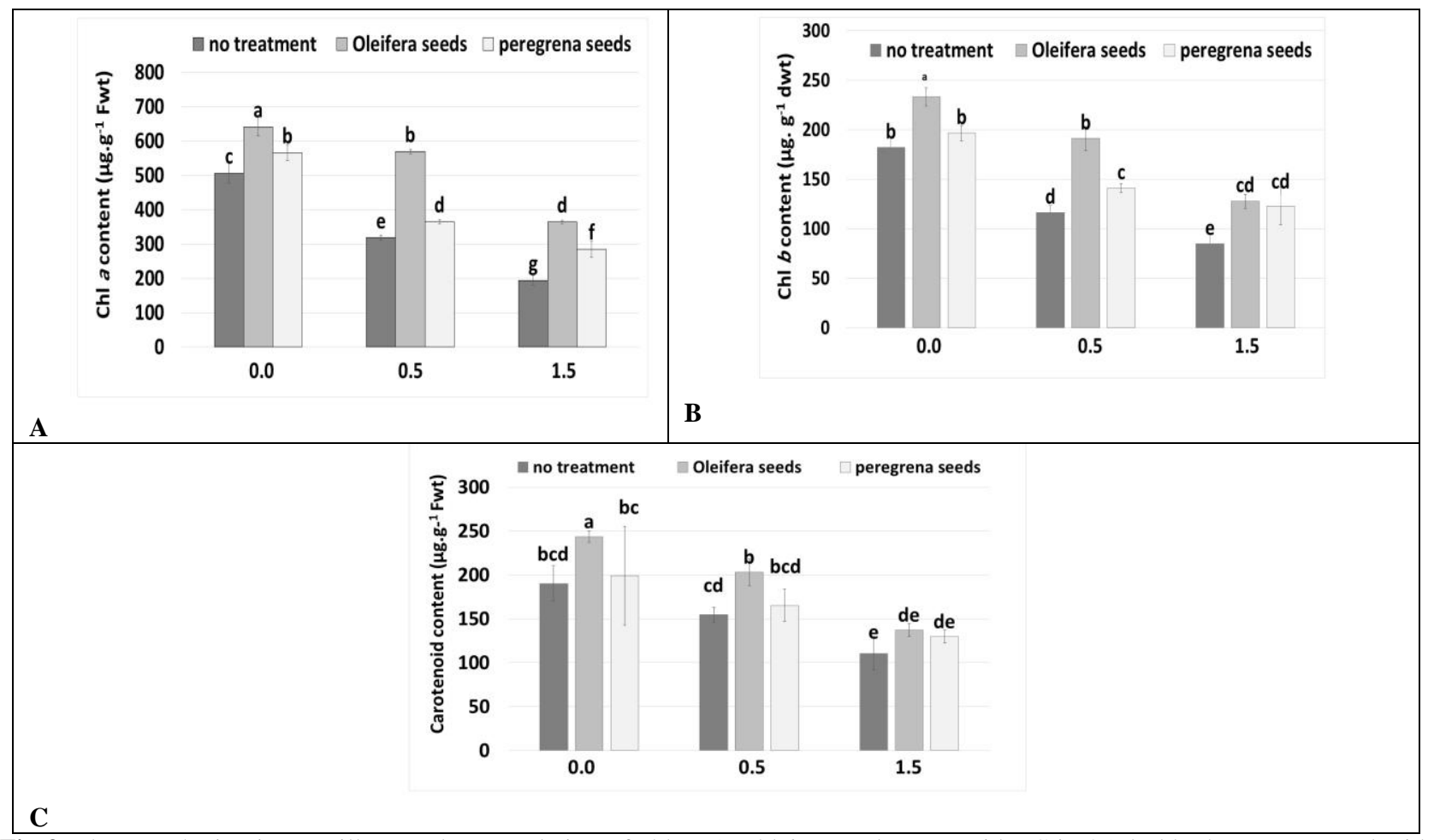

Fig 3. Photosynthetic pigment illustrated accumulation of chl $a$; $\mathrm{A}$, chl $b$; B and carotenoids; $\mathrm{C}$ in $35 \mathrm{~d}$ old wheat pre-treated with defatted seeds from Moringa oleifera and Moringa peregrena prior grown without cadmium (0.0) or with Cd: 0.5, 1.5 mM. Bars associated with different letters are significantly different (one-way Anova, LSD test, $p \leqslant 0.05$ ).

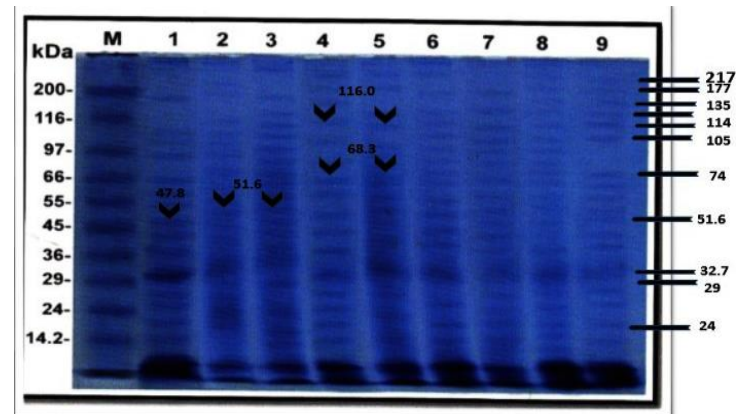

Fig 4. SDS-PAGE gel electrophoresis views profile of purified soluble protein from 35-d old wheat leaf grown in water, lane 1; or with cadmium: $0.5 \mathrm{mM} \mathrm{Cd}$, lane $2 ; 1.5 \mathrm{mM} \mathrm{Cd}$, lane 3. Pre-treated wheat with M. oleifera, lane 4; or with $M$. peregrena, lane 5. Grown wheat in response to $M$. oleifera and $0.5 \mathrm{mM} \mathrm{Cd}$, lane 6; M. peregrena and $0.5 \mathrm{mM} \mathrm{Cd,} \mathrm{lane} \mathrm{7;} 1.5 \mathrm{mM} \mathrm{Cd}$ and M. oleifera, lane $8 ; 1.5 \mathrm{mM} \mathrm{Cd}$ and M. peregrena, lane 9. Marker; M. Long arrows pointed to the expressed new protein bands in lanes from 6-9. Short arrows detected characteristic protein bands in lanes;1-5. 
and root and induced up-regulations in the growth parameters and in photosynthetic pigments. The coagulation mechanism was likely a result of electrostatic interactions and formation of complexes between the metal ions and some functional groups of carbohydrates, lipids, lignin or proteins (Meneghel et al., 2013). However, Yongabi et al., 2011, suggested that protein is the active operator component of coagulation process. For example, the proteins weighed from 12-14 KDa designated as water-soluble polypeptides capable of coagulating wastes from turbid water (Santos et al., 2012).

In addition, Agrawal et al., 2007 had extracted and purified $66 \mathrm{KDa}$ then discovered that purification of protein is much more efficient than using seeds crude extracts of active components in absence of purified protein.

Our data highlighted Cd treatment and its subsequent effect on plant toxicity after cadmium uptake, distribution and accumulation in the root and shoot. Since metal uptake from culture soil was concentration-dependent, wheat roots had accumulated higher amounts of cadmium as compared to shoots (Vamerali et al. 2012). In addition, cadmium had seriously inhibited relative water content and supressed growth parameters including; shoot length, fresh and dry weights in shoot and root (Raziuddin et al., 2011). These morphological changes were reported to be symptoms of reduced chlorophyll synthesis and of diminished photosynthetic rate (Padmaja et al., 1990). However, the inhibition of photosynthesis usually resulted from chloroplast suppression, and from inhibition of cell division and replication (Baryla et al., 2001). Cadmium roles in stomatal closure and in mediating the decrease of leaf conductance and in disturbing hormonal balance were reported (PerfusBarbeoch et al., 2002).

Moreover, cadmium stress had affected the photosynthetic pigments likely due to substitution of $\mathrm{Mg}$ ion with cadmium in chlorophyll molecule, or for activation of chlorophyllase enzyme (Vassilev and Yordanov, 1997). Application of defatted seeds viewed the surpassed role of OS compared to PS in alleviation of cadmium toxicity. Recently, Emmanuel et al., 2011, reported that OS is an active bio fertilizer contained high content of phytohormones, macro, micronutrients and antioxidant compounds such as ascorbic acid, reduced glutathione and total phenol.

As previously reported, cadmium was responsible for the expression of various proteins in contaminated plants (Kranner and Colville, 2012). In this current study, five protein bands $(217.77,135.4,51.6,45.0,38.2 \mathrm{KDa})$ were expressed in contaminated wheat with cadmium and they were believed to be Cd stress proteins. When Moringa seeds were applied in absence of cadmium, the number of new bands in wheat was seven bands. Following the addition of cadmium in the culture soil, the total sum of the new protein bands raised to eleven bands. These proteins were involved as oxidative scavengers of the reactive oxygen species, and interacted with the aldehyde products that usually release from lipid peroxidation (Sandalio et al., 2001). The role of newly expressed proteins in binding $\mathrm{Cd}$ ion forming polychelatins and metallothioneins, then placed them in the vacuole was also suggested (Maheshwari and Dubey, 2008).

\section{Materials and Methods}

\section{Plant material and cadmium treatment}

The detoxification experiments using defatted seeds from Moringa species were carried out on wheat (Triticum aestivum L.) plant. Seeds from two mature cultivated Moringa trees: M. Oleifera Lam and M. peregrine Foressk grown in El-Orman garden, El-kanater El-khairia, Kalubiah governorate, Egypt-were collected during June/ 2015. Defatted seeds; 'the seeds lacking fats, in this case oil'. The defatting process was achieved by air-drying Moringa seeds before extracting oil content from the seeds using 70\% nhexane in a working Soxhlet apparatus for $18 \mathrm{hrs}$ (Meara, 1995). The seed cake was air-dried again to evaporate the solvent, then ground to powder using a domestic electrical blender before been used. Wheat grains were surface sterilized using $1 \%$ sodium hypochlorite $(\mathrm{NaClO})$ solution then washed for 5 minutes using distilled water. The grains were planted in plastic pods filled with $3 \mathrm{~kg}$ soil in a temperature-adjusted growth chamber at $28^{\circ} / 18^{\circ} \mathrm{C}$ (day/night).

The effect of cadmium was investigated by using $\mathrm{Cd}$ acetate; the fine chemical which was purchased from Sigma Aldrich company. The following concentrations of $\mathrm{Cd}$ in distilled water were prepared and kept at $4^{\circ} \mathrm{C}$ : 0, 0.5, 1.0, 1.5 $\mathrm{mM}$ ). Before cadmium was applied, three grams of Moringa seed cake were added to each pod (referred to as oleifera seeds, peregrena seeds in the figures) for one week started from planting date. The experiments were set up as follow: pods with one type of seed cake from one Moringa species, pods with no treatment, and pods with seed cakes in the soil and $\mathrm{Cd}$ applications in soil solution. Wheat cultures were left to grow for total 35 days then the physiological parameters as well as Cd uptake were analyzed (Foidle et al., 2001).

\section{Determination of cadmium uptake in wheat shoot and root}

Cadmium determination was performed according to the method described by Ciobanu et al., 2013. Homogenized 20 grams of fresh wheat shoots and roots were kept overnight at $105^{\circ}$. The samples were dried to ash at $450^{\circ} \mathrm{C}$ with a muffle furnace (Nabertherm, Germany) until the ash residue became white or grey. The residue was treated with $5 \mathrm{ml} \mathrm{HNO}_{3}$ $(65 \%)$ and maintained on a sand bath at a temperature of approximately $150^{\circ} \mathrm{C}$ to dissolve the remaining ash. The solution was filtered and completed to $25 \mathrm{ml}$ with purified water. A blank digest was carried out in the same way. Cadmium concentration was determined in air-acetylene flame by HR-CS AAS (High Resolution Continuum Source Atomic Absorbtion Spectrometry, ContrAA 300, Analytic Jena, Germany).

\section{Determination of the relative water content $(\% R W C)$}

Relative water content (RWC) was determined in $2 \mathrm{~cm}^{2}$ segments of fresh leaf. Segments were weighed quickly and immediately floated on distilled water in petri dishes to saturate them with water for about 24 hours in dark. The adhering water of the segments was blotted and the turgor mass was determined. Dry mass of the segment was recorded after dehydration at $70 \%$ for $48 \mathrm{~h}$. Percentage of RWC was calculated using the following formula:

\section{RWC $=$ Fresh mass - dry mass/Turgor mass - drymass X100 (Hayat et al.2007)}

4.4 Extraction and determination of photosynthetic pigments The photosynthetic pigments ( $\mathrm{Chl} a, b$ and carotenoids) were determined using a spectroscopic method described by Metzner et al., 1965. Leaf fresh weight $(0.5 \mathrm{~g})$ was homogenized in $85 \%$ aqueous acetone for 5 minutes. The homogenate was centrifuges and the supernatant was made up to $10 \mathrm{ml}$ with $85 \%$ aqueous acetone. The optical densities were measured against a blank of pure $85 \%$ acetone using spectronic 601 spectophotometer. The concentrations of each 
pigment (chlorophyll $a$, chlorophyll $b$ and carotenoids) can be determined as $\mu \mathrm{g} / \mathrm{g}$ fresh weight of leaves and calculated using the following equations:

$$
\begin{gathered}
\text { Chl } a=10.3 \mathrm{E} 663-0.918 \mathrm{E} 644 \mu \mathrm{g} / \mathrm{ml} \\
\text { Chl } b=19.7 \mathrm{E} 644-3.870 \mathrm{E} 663 \mu \mathrm{g} / \mathrm{ml} \\
\text { Carotenoids }=4.2 \mathrm{E} 452.5-(0.0264 \mathrm{chl} \mathrm{a}+0.426 \mathrm{chl} \mathrm{b}) \mu \mathrm{g} / \mathrm{ml}
\end{gathered}
$$

Extraction and estimation of protein using sodium dodecyl sulphate polyacrylamide gel electrophoresis (SDS-PAGE) Extraction

Fresh leaves were ground in liquid nitrogen to fine powder. 3 mls of Tris buffer ( $\mathrm{pH} 8.5$, Trizma base, $2.442 \mathrm{~g}$; sucrose, 10 g; SDS, $2.0 \mathrm{~g}$; 2-mercaptoethanol, $5 \mathrm{ml}$ in $100 \mathrm{ml}$ distilled water) were added per gram fresh weight. The homogenate was centrifuged using bench centrifuge for $20 \mathrm{~min}$. at 1200 $\mathrm{xg}$. The samples stored at $-80{ }^{\circ} \mathrm{C}$ or immediately been loaded.

\section{Gel preparation}

Preparation of the stacking and separating gels was performed according to Hames and Rickwood, 1981. Samples were loaded using micropipette, they were electrophoresed for 8-9 h then were stained with coomasie brilliant blue overnight.

\section{Densitometric scanning}

For quantitative analysis of the gel pattern, densitometry was used for imaging the stained gel profiles (densitometer, $\mathrm{HeNe}$ $633 \mathrm{~nm}$ laser light source). A complete chart recorded an output of the data as qualified protein values at different $R_{f s}$ as measuring the area under the printed individual peak by means of automated integrator. The banding profile in the gel was photographed and the number of bands was scored.

\section{Statistical analysis}

All the data were means of three replicates. The statistical analyses were performed using the SPSS software ver. 17. A one-way analysis of variance (ANOVA), LSD test, $p \leqslant 0.05$ applied for the determination of significant differences involving more than two samples.

\section{Conclusion}

In this study, we highlighted a correlation between the increased cadmium accumulation in wheat plants with its increased level in culture solution. The otherwise major role of Moringa oleifera and Moringa peregrena in maintaining overall wheat growth and pigment content was studied. The early treatment using Moringa defatted seed-cake powder prior wheat exposure to cadmium had resulted in the expression of new proteins with specific molecular weights in the leaf. These protein bands had sustained the recovery process due to Moringa double role as Cd coagulants in soil and in wheat. The expressed protein molecules were also scavengers of released reactive oxygen species upon cadmium contamination. Moringa peregrena role as $\mathrm{Cd}-$ remediator was discovered here although was less important as compared to Moringa oleifera. However, both Moringa species were potent in reinforcing crop plants tolerance against cadmium in safe manner.

\section{Acknowledgement}

We thank the manager of El-Orman garden for collaboration and we owe great debt to Ain-shams University for finance.

\section{References}

Abd El-|Wahab RH, Zaghloul MS, Moustafa AA (2004) Conservation of medicinal plants in St. Catherine Protectorate, South Sinai. I. Evaluation of ecological status and human impact. Proceedings of First International of Conference on Strategy of Egyptian Herbaria. (Giza, Egypt). 231251.

Agrawal S, Shaheen R (2007) Stimulation of antioxidant system and lipid peroxidation by abiotic stress in leaves of Momordica charantia. Braz J Plant Physiol. 19: 149-161.

Ahluwalia SS, Goyal D (2007) Microbial and plant derived biomass for removal of heavy metals from waste water. Bioresource Technol. 98: 2243-2257.

Alkahtani HA, Abou-Arab AA (1993) Comparison of physical, chemical, and functional properties of Moringa peregrena (Al-Yassar or Al-Ban) and soybean proteins. Cereal Chem. 70: 619-626.

Baptistaa, ATA, Silvab MO, Gomesc RG, Bergamascod R, Vieirad MF, Vieira AMS (2017) Protein fractionation of seeds of Moringa oleifera lam and its application in superficial water treatment. Sep Purif Technol. 180: 114124

Baryla A, Carrier P, Franck F, Coulomb C, Sahut C, Havaux M (2001) Leaf chlorosis in oilseed rape plants (Brassica napus) grown on cadmium-polluted soil: causes and consequences for photosynthesis and growth. Planta. 212 (5): 696-709.

Bazrafshan E, Faridi H, Pour M, Kord F, Mahvi AH (2013) Removal of arsenic from aqueous environments using Moringa peregrena seed extract as a natural. Asian J Chem. 25: 3557-3561.

Choong SY, Chuah TG, Robiah Y, Koay FLG, Azni I (2007) Arsenic toxicity, health hazards and removal techniques from water: an overview. Desalination. 217: 139-166.

Ciobanu C, Lencu BG, Cucireanu R (2013) Faas determination of cadmium and lead content in foodstuffs from north-eastern Romanian market. Studia Universitatis "Vasile Goldiş", Seria Ştiinţele Vieţii. 23: 33-38.

Coppin JP, Xu Y, Chen H, Pan MH, Ho C, Juliani R, Simon JE, Wu Q (2013) Determination of flavonoids by LC/MS and anti-inflammatory activity in Moringa oleifera. J Funct Food. 5: 1892-1899.

Derbyshire E, Wright DJ, Boulter (1976) Legumin and vicillin, storage proteins of legume seeds. Phytochem. 15: 3 .

Emmanuel SA, Zaku SG, Adedirin SO, Tafida M, Thomas SA (2011) Moringa oleifera seed cake, alternative biodegradable and biocompatibility organic fertilizer for modern farming. ABJNA. 2: 1289-1292.

Foidle G, Makkar HPS, Becker K (2001) The potential of Moringa oleifera for agricultural and industrial uses. In: Fugile, 1 (Ed.). The Miracle tree: The multipurpose attributes of Moringa. CTA. Publications Wageningen. The Netherlands, pp:45-76.

Gassenschmidt U, Jany KD, Tauscher B, Niebergall H (1995) Isolation and characterization of a flocculating protein from Moringa oleifera Lam. Biochem Biophys Acts. 1243: 477-481. 
Guo J, Dai X, Xu W, Ma M (2008) Overexpressing GSHI and AsPCSI simultaneously increases the tolerance and accumulation of cadmium and arsenic in Arabidopsis thaliana. Chemosphere. 72(7): 1020-1026.

Hames BD, Rickwood D (1981) An introduction to polyacrylamide gel electrophoresis, in: gel electrophoresis of proteins: a practical approach (B. D Hames and D. Rickwood, eds.), pp. 1-86, IRL press. Oxford, England.

Hayat S, Ali B, Hasan SA, Ahmed A (2007) Brassinosteroid enhanced the level of antioxidant sunder cadmium stress in Brassica juncea. Environ Exp Bot. 60: 33-41.

Himesh A, Chandan S, Ashwani KS (2007) Isolation of a 66 $\mathrm{KDa}$ protein with coagulation activity from seeds of Moringa oleifera. Res J Agr Biol Sci. 3: 418-421.

Iqbal S, Bhanger MI (2006) Effect of season and production location on antioxidant activity of Moringa oleifera leaves grown in Pakistan. J Food Comp Anal. 19: 544-551.

Juliana HR, Fonseca Y, Acquaye D, Malumo H, Malainy D, Simon JE (2009) Nutritional assessment of moringa (Moringa oleifera) from Ghana, Senegal and Zambia. In H. R. Juliana, J. E. Simon, \& C. T. Ho (Eds.), Afr nat plant product: New discoveries and challenges in chemistry and quality. ACS symposium series (pp. 469-484). Washington, D.C.: American Chemical Society.

Kranner I, Colville L (2012) Metals and seeds: biochemical and molecular implications and their significance for seed germination. Environ Exp Bot.72: 93-105.

Lenardao E., Freitag RA, Dabdoub MJ, Batista ASF, Silveira CC (2003) Green-chemistry- the 12 principles of green chemistry and it insertion in teach and research activities. Quimica Nova. 26: 123-129.

Mahdavi S, Jalali M, Afkhami A (2012) Removal of heavy metals from aqueous solutions using $\mathrm{Fe}_{3} \mathrm{O}_{4}, \mathrm{ZnO}$ and $\mathrm{CuO}$ nanoparticles. J Nanopart Res. 14: 846.

Maheshwari R., Dubey R (2008) Inhibition of ribonuclease and protease activities in germinating rice seeds exposed to nickel. Acta Physiol Plant. 30: 863-872.

Meara ML (1955) Fats and other lipids in "Modern methods of plant analysis" (Ed. By K. Paech and M. V. Tracey). 11:317-402. Springer-Verlag, Berlin.

Meneghel AP, Goncalves JRAC, Dragunski DC, Rubio F, Lindino CA, Strey L (2013) Biosorption of cadmium from water using Moringa (Moringa oleifera Lam.) seeds. Water Air Soil Poll. 224: 1383-1395.

Metzner H, Rau H, Senger H (1965) Uentersuchungen zur synchronisier barkeit einzelnerpigment. mangol mutanten von chloella. Planta. 65:186-194.

Nautiyal BP, Venkataramen KS (1998) Quality of water treated by coagulation using Moringa peregrena seeds. Water Res. 32(3): 781-791.

Ndabigengeser A, Narasiah KS (1998) Quality of water treated by coagulation using Moringa oleifera seeds. Water Res. 32(3): 781-791.

Ndabigengesere A, Narasiah KS, Talbot BG (1995) Active agents and mechanism of coagulation of turbid waters using Moringa oleifera. Water Res. 29: 703-710.

Okuda T, Baes AU, Nishijima W, Okada M (2001) Isolation and characterization of extracted from Moringa oleifera seed by salt solution. Water Res. 35(2): 405-410.

Padmaja K, Prasad DDK, Prasad ARK (1990) Inhibition of chlorophyll synthesis in Phaseolus vulgaris L. seedlings by cadmium acetate. Photosynthetica. 24(3): 399-405.

Perfus-Barbeoch L, Leonhardt N, Vavasseur A, Forestier C (2002) Heavy metal toxicity: cadmium permeates through calcium channels and disturbs the plant water status. Plant J. 32(4): 539-548.
Qaiser M (1973) Moringaceae. In: Nasir, E., Ali, S.I. (eds.), Flora of West Pakistan, vol. Department of Botany, University of Karachi, Karachi, Pakistan. 38: 1-4.

Raziuddin F, Hassan G, Akmal M, Shah SS, Mohammed F, Shafi M, Bakht J, Zhou W (2011) Effects of cadmium and salinity on growth and photosynthesis parameters of Brassia species. Pak J Bot. 43(1): 333-340.

Sandalio LM, Daluzo HC, Gomez M, Romero-Puertas MC, Del Rio LA (2001) Cadmium induced changes in the growth and oxidative metabolism of pea plants. J Exp Bot. 52: $2115-2126$.

Sarwatt SV, Kapange SS, Kakengi AMV (2002) Substituting sunflower seed-cake with Moringa oleifera leaves as a supplementat goat feed in Tanzania. Agroforest Syst. 56(3): 241-247.

Suarez M, Entenza JM, Doerries C, Meyer E, Bourquin L, Sutherland J, Marison, I, Moreillon P (2003) Expression of a plant-derived peptide harboring water-cleaning and antimicrobial activities. Biotechnol Bioeng. 81: 13-20.

Sengupta A, Gupta MP (1970) Studies on the seed fat composition of Moringaceae family. Fett Wiss Technol.72: 6-10.

Perfus-Barbeoch L, Leonhardt N, Vavasseur A, Forestier C (2002) Heavy metal toxicity: cadmium parameters through calcium channels and disturbs the plant water status. Plant J. 32: 539-548.

Santana CR, Pereira DF, NA, Araujo NA, Cavalcanti EB, Silva GF (2010) Physical chemical characterization of the Moringa Lam. (Moringa oleifera Lam.). Rev Bras Prod Agr.12: 55-60.

Santos ME, Athanasiadis A, Leitao AB, Dupasquier L, Sucena E (2011) Alternative splicing and gene duplication in the evolution of the FoxP gene subfamily. Mol Biol Evol. 28(1): 237-247.

Santos AF, Argolo AC, Paiva PM, Coelho LC (2012) Antioxidant activity of Moringa oleifera tissue extracts. Phytother Res. 26: 1366-1370.

Vamerali T, Marchiol L, Bandiera M, Fellet G, Dickinson NM, Lucchini P, Mosca G, Zerbi G (2012) Advances in agronomic management of phytoremediation: Methods and results from a 10-year study of metal polluted soils. Ital J Agron. 7:(42): 323-330.

Vassilev A, Yordanov I (1997) Reductive analysis of factors limiting growth of cadmium-treated plants: a review. Bulg J Plant Physiol. 23: 114-133.

Vlahof G, Chepkwony PK, Ndalut PK (2002) 13 C NMR characterization of triacyl glycerols of Moringa oleifera seed oil: An Oleic-Vaccenic acid oil. J Agr Food Chem. 50: 970-975.

Wan Ngah WS, MAK Hanafiah (2008) Biosorption of copper ions from dilute aqueous solutions on base treated rubber (Hevea brasiliensis) leaves powder: kinetics, isotherm, and biosorption mechanisms. J Environ Sci. 20: 1168-1176.

Yongabi KA, Lewis DM, Harris PL (2011) A Moringa oleifera disinfectant-sand filter integration: a review of an alternative sustainable technology for household water treatment. J Environ Sci Eng. 5: 1100-1108.

Yurtsever M, Sengil IA (2009) Biosorption of Pb (II) ions by modified querbracho tannin resin. J Hazard Mater. 163: 5864. 